\title{
MDMA alone affects sensorimotor and prepulse inhibition responses in mice and rats: tips in the debate on potential MDMA unsafety in human activity
}

\author{
Matteo Marti ${ }^{1,2,3} \cdot$ Margherita Neri $^{1} \cdot$ Sabrine Bilel ${ }^{1} \cdot$ Marco Di Paolo $^{4} \cdot$ Raffaele La Russa $^{5} \cdot$ Andrea Ossato $^{6}$. \\ Emanuela Turillazzi ${ }^{4}$
}

Received: 5 June 2018 / Accepted: 9 September 2018

(c) Japanese Association of Forensic Toxicology and Springer Japan KK, part of Springer Nature 2018

\begin{abstract}
Purpose MDMA is a psychoactive drug that has been increasingly abused worldwide, due to its entactogenic properties. However, concerns on its safety exist, particularly regarding its effects on attentional skills and performance. Evidence from the literature shows contrasting effects of MDMA. It generally acts as a pshychomotor stimulant, thus improving arousal and psychomotor function. However, MDMA has been demonstrated to negatively influence other skills. Consequently, human activities that require alertness, and accurate and quick reflexes (i.e. driving, operations at the workplace, etc.) could be negatively affected. In the present study, the effect of MDMA $(0.1-20 \mathrm{mg} / \mathrm{kg}$, intraperitoneally) on sensorimotor and startle/ prepulse inhibition responses was evaluated in a controlled rodent experimental setting.

Methods Sensorimotor studies, evaluation of visual, acoustic, and tactile responses, evaluation of spontaneous locomotion, startle and repulse inhibition analyses were performed in an experimental controlled rodent model (rats and mice), following the administration of MDMA $(0.1-20 \mathrm{mg} / \mathrm{kg})$ intraperitoneally.

Results Our findings show that all the MDMA-treated animals had impaired sensorimotor and prepulse inhibition responses compared to the control subjects at the early (5,30 and $60 \mathrm{~min}$ ) testing time points while all the effects disappeared, respectively, 6, 16 and $24 \mathrm{~h}$ post-MDMA treatment.

Conclusions Within the ongoing debate on the safety of recreational abuse of MDMA, our results reveal acute prominent changes in sensorimotor and attentional performance, sensor response to external stimuli, and locomotor activity due to a single administration of a dose of MDMA (corresponding to a dose producing in humans both 'desirable' entactogenic effects and physiological adverse effects).
\end{abstract}

Keywords MDMA $\cdot$ Sensorimotor responses $\cdot$ Attentional skills $\cdot$ Human activities $\cdot$ Safety

Emanuela Turillazzi

emanuela_turillazzi@inwind.it

1 Department of Morphology, Experimental Medicine and Surgery, Section of Legal Medicine, University of Ferrara, Ferrara, Italy

2 Centre for Neuroscience and National Institute of Neuroscience, Rome, Italy

3 Collaborative Centre for the Italian National Early Warning System, Department of Anti-Drug Policies, Presidency of the Council of Ministers, Rome, Italy
4 Section of Legal Medicine, Department of Surgical, Medical, Molecular Pathology and Critical Medicine, University of Pisa, via Roma, Pisa, Italy

5 Department of Anatomical, Histological, Forensic and Orthopaedic Sciences, Sapienza University of Rome, Rome, Italy

6 Department of Life Sciences and Biotechnology (SVeB), University of Ferrara, Ferrara, Italy 


\section{Introduction}

3,4-Methylenedioxymethylamphetamine or MDMA, also known as 'ecstasy' or 'molly', is an increasingly abused psychoactive drug. There is widespread concern for potential MDMA abuse and for the possible reduced perception of associated risks [1].

MDMA is a recreationally-used drug, due to the fact that it is an entactogen [2], and enhances energy, endurance, sociability, openness, positive mood, calmness, self-esteem and self-confidence, and sexual arousal [3]. These 'positive' effects constitute the generally reported main reasons for MDMA use given by ecstasy users [4]. However, concerns regarding its safety and neurotoxic profile are on the increase $[5,6]$.

Acute MDMA toxicity, widely documented both in humans and in animal models, mainly regards effects on the neuroendocrine, thermoregulatory, and cardiovascular systems [7].

A particularly debated issue is the effect of MDMA assumption on attentional skills and performance [8]. Evidence from the literature shows the different effects of MDMA. It generally acts as a psychomotor stimulant, thus improving arousal and psychomotor function. Accordingly, several authors report that MDMA could increase tracking performance [9], psychomotor speed [9, 10], and impulse control [11]. However, evidence of the opposite effects exists. In fact, it has been shown that MDMA negatively influences other skills such as spatial memory performance [12], movement perception [12] and divided attention [9]. Consequently, human activities that require alertness, accurate and quick reflexes (i.e., driving, operations at the workplace, etc.) could be adversely affected [13, 14]. MDMA and its metabolites have frequently been found in the biological samples of people involved in traffic accidents $[9,15]$, thus suggesting that MDMA could affect driving performance [16]. Similarly, it is widely reported that the use of alcohol and drugs may reduce workplace safety [17]. However, as in many other drugs of abuse, data from MDMA users are often difficult to interpret, as they are frequently grounded on self-reported variables of time and dose through the use of questionnaires [18], are confused by polydrug abuse that may interact with MDMA itself [19], and, finally, by high dose variability in ecstasy tablets [20].

Moving from the above considerations, we aimed to investigate if the administration of pure MDMA compound to experimental animal models (rat and mouse) with controlled dosing $(0.1-20 \mathrm{mg} / \mathrm{kg}$, intraperitoneally) and housing regimens may alter the ability of animals to receive and integrate sensory stimuli. To this aim we investigated the effect of MDMA on sensorimotor (visual, acoustic and tactile) alterations and on startle/prepulse inhibition responses in both rats and mice. Moreover, the effects of MDMA on spontaneous locomotion were investigated.

\section{Materials and methods}

\section{Animals}

Ninety male outbred ICR mice $\left(\mathrm{CD}-1^{\circledR}\right.$; Harlan Italy; S. Pietro al Natisone, Italy) weighing 25-30 g (group-housed 8-10 mice per cage; floor area per animal was $80 \mathrm{~cm}^{2}$; minimum enclosure height was $12 \mathrm{~cm}$ ) and 90 male albino rats (Wistar; Charles River) weighing 200-250 g (group-housed six rats per cage) were housed in a colony room with constant temperature $\left(20-22{ }^{\circ} \mathrm{C}\right)$ and humidity $(45-55 \%)$. Food (Diet 4RF25 GLP; Mucedola, Settimo Milanese, Milan, Italy) and tap water were available ad libitum all the time the animals spent in their home cages. The daylight cycle was maintained artificially (dark between $6 \mathrm{pm}$ and $6 \mathrm{am}$ ). Experiments were performed during the light phase and each mouse was used for only one experiment. Experimental protocols performed in the present study were in accordance with the new European Communities Council Directive of September 2010 (2010/63/EU), a revision of the Directive $86 / 609 / \mathrm{EEC}$, and were approved by the Italian Ministry of Health (licence n. 335/2016-PR) and by the Ethics Committee of the University of Ferrara. Moreover, adequate measures were taken to minimize the number of animals used as well as their pain and discomfort. We made every effort to minimize pain and suffering, and to reduce the number of animals used. In behavioural studies for each treatment (saline or MDMA $0.1-20 \mathrm{mg} / \mathrm{kg}$ ) we used eight mice or rats, while in startle/prepulse inhibition studies for each treatment (saline or MDMA $0.1-20 \mathrm{mg} / \mathrm{kg}$ ) we used ten mice or rats.

\section{Drug Preparation and dose selection}

MDMA, purchased from LGC Standards S.r.l (Milan, Italy), was dissolved in saline solution and administered intraperitoneally (i.p.) in mice (at a volume of $4 \mu \mathrm{l} / \mathrm{g}$ ) or rats $(0.7 \mu \mathrm{l} / \mathrm{g})$. The highest dose used for MDMA $(20 \mathrm{mg} / \mathrm{kg}$ i.p. $)$ was chosen based on both previous preliminary studies on rodents [21, 22] and on behavioural and neurological effects reported in human subjects (https://erowid.org/chemicals/ mdma/mdma_dose.shtml) [8].

Indeed, considering the human experiences of consumers of MDMA [8], it can be assumed that a typical recreational MDMA dose (75-125 mg) produces pleasurable and dysperceptive effects, feelings of euphoria and stimulation [23], but also tachycardia, trismus, and bruxism, while a higher MDMA dose $(\sim 200 \mathrm{mg})$ is considered a strong dosage that causes adverse effects. Using interspecies dose scaling, a drug dose of $20 \mathrm{mg} / \mathrm{kg}$ in a mouse is equivalent 
to that assumed by a human being weighing $70 \mathrm{~kg}$ taking a dose of $\sim 1.62 \mathrm{mg} / \mathrm{kg}$ orally (a tablet containing $\sim 113 \mathrm{mg}$ of MDMA) while $20 \mathrm{mg} / \mathrm{kg}$ in rats is equivalent to that assumed by a human being weighing $70 \mathrm{~kg}$ taking a dose of $3 \mathrm{mg} / \mathrm{kg}$ orally (a tablet containing $200 \mathrm{mg}$ of MDMA). MDMA or saline solution was administered 5 min before the beginning of the tests.

\section{Behavioural studies}

The effects of MDMA $(0.1-20 \mathrm{mg} / \mathrm{kg}$, i.p. $)$ were investigated using a battery of behavioural tests widely used in studies of 'safety-pharmacology' for the preclinical characterization of new molecules in rodents [24]. These tests have also been validated to describe the pharmacological and toxicological effects of novel psychoactive substances [25, 26]. To reduce the animals' stress induced by manipulation, and to confirm the stability and reproducibility over time of the responses to our tests, animals were trained twice a week for 2 weeks before the pharmacological treatment. All experiments were performed between 8.30 a.m. and 2 p.m. Experiments were conducted in blind by trained observers working together in pairs [27]. The behaviour of mice/rats (sensorimotor responses) was videotaped and analysed off-line by a different trained operator who gave test scores.

\section{Sensorimotor studies}

We studied the voluntary and involuntary sensorimotor responses resulting from different mouse/rat reactions to visual, acoustic and tactile stimuli [26]. In animals, including humans, the startle response is a largely unconscious defensive response to sudden or threatening stimuli, such as a sudden noise or sharp movement, and is associated with negative effects. Usually the onset of the startle response is a startle reflex reaction, a brainstem reflectory reaction (reflex) that serves to protect vulnerable parts, such as the back of the neck (whole-body startle) and the eyes (eyeblink) and facilitates escape from sudden stimuli [28].

Evaluation of the visual response Visual response was verified by two behavioural tests, which evaluated the ability of the mouse/rat to capture visual information both when the animal is stationary (the visual object response) and when it is moving (the visual placing response). A visual object response test was utilized to evaluate the ability of the rodent to see an object approaching from the front or the side, then inducing the animal to shift or turn the head or withdraw it [26]. For the frontal visual response, a white horizontal bar moved frontally to the mouse/rat head, and the manoeuvre was repeated three times. For the lateral visual response, a small dentist's mirror was moved into the animal's field of vision in a horizontal arc, until the stimulus was between the rodent's eyes. The procedure was conducted bilaterally and repeated three times. The score assigned was a value of 1 if there was a reflection in the rodent movement or 0 if not. The total value was calculated by adding the scores obtained in the frontal with that obtained in the lateral visual object response (overall score 9). Evaluation of the visual object response was measured at $0,5,30,60 \mathrm{~min}$ and 6,16 and $24 \mathrm{~h}$ post injection.

A visual placing response test was performed using a tail suspension modified apparatus able to bring down the animal towards the floor at a constant speed of $10 \mathrm{~cm} / \mathrm{s} \mathrm{[26].}$ The downward movement of the mouse/rat was videotaped. The frame by frame analysis allows us to evaluate the beginning of the reaction of the animal while it is close to the floor. When the animal's reaction starts, an electronic ruler evaluates the perpendicular distance in millimetres between the eyes of the rodent to the floor. Untreated animals perceive the floor and prepare for contact at a distance of about $28 \pm 3.5 \mathrm{~mm}$ (rats) and $19 \pm 3.6 \mathrm{~mm}$ (mice). Evaluation of the visual placing response was measured at $0,10,35$, 65 min and 6, 16 and 24 h post injection.

Evaluation of acoustic response Acoustic response measures the sensorimotor reaction of the mouse/rat in replay to an acoustic stimulus produced behind the animal [28]. In particular, four acoustic stimuli of differing intensity and frequency were tested [26]. A snap of the fingers (four snaps repeated in $1.5 \mathrm{~s}$ ), a sharp click (produced by a metal instrument; four clicks repeated in $1.5 \mathrm{~s}$ ), an acute sound (produced by an audiometer that reproduces a highpitched sound at a frequency of around $5.0-5.1 \mathrm{kHz}$ ) and a severe sound (produced by an audiometer that reproduces a sound at a frequency of around $125-150 \mathrm{~Hz}$ ). Each test was repeated three times, giving a value of 1 if there was a response, or 0 if not present, for a total score of 3 for each sound. The acoustic total score was calculated by adding scores obtained in the four tests (overall score 12). Background noise (about $40 \pm 4 \mathrm{~d}, \mathrm{~B}$ ) and the sound from the instruments were measured with a digital sound level meter. Evaluation of the acoustic response was measured at 0,10 , $35,65 \mathrm{~min}$ and 6,16 and $24 \mathrm{~h}$ post injection.

Evaluation of tactile response The tactile response was verified through vibrissae, pinna and corneal reflexes [26]. Evaluation of the tactile responses was measured at 0, 5, 30, 60 min and 6, 16 and $24 \mathrm{~h}$ post injection.

Vibrissae reflex was evaluated by touching vibrissae (right and left) with a thin hypodermic needle once per side giving a value of 1 if there was a reflex (turning of the head to the side of touch or vibrissae movement) or 0 if not present (overall score 2).

Pinna reflex was assessed by touching pavilions (left and right, firstly the interior and then the external), with a thin 
hypodermic needle. The test was repeated twice for both sides, assigning a value of 1 if there was a reflex and 0 if not present (overall score 4).

Corneal reflex was assessed gently touching the cornea of the mouse/rat with a thin hypodermic needle and evaluating the response, assigning a value of 1 if the rat moved only the head, 2 if it only closed the eyelid, 3 if it closed the lid and moved the head. The procedure was conducted bilaterally (overall score 6)

\section{Evaluation of spontaneous locomotion}

Since MDMA-induced hyperlocomotion [29] has been described in rodents, we investigated, in our controlled experimental setup, the effects of the administration of increasing doses of MDMA $(0.1-20 \mathrm{mg} / \mathrm{kg}$, i.p.) on spontaneous motor activity.

Spontaneous locomotor activity was investigated by using a camera (B/W USB Camera day and night with varifocal lens; Ugo Basile, Italy) and films were analysed off-line by a trained operator who did not know the drug treatments performed. The mouse/rat was placed in a square plastic cage $(60 \times 60 \mathrm{~cm})$ located in a sound- and light-attenuated room and horizontal motor activity (in s) and turning behaviour (number of rotations) were monitored for $5 \mathrm{~min}$ at each time point $(0,10,35,65$ min and $6,16,24$ h post injection). To avoid rodents' olfactory cues, cages were carefully cleaned with a diluted (5\%) ethanol solution and washed with water between animal trials.

\section{Startle and repulse inhibition analysis}

Considering the fact that MDMA impairs startle/prepulse inhibition (startle/PPI) paradigm in rats [30] and in some strains of mice [31], in our controlled experimental setup we investigated the effects of the administration of increasing doses of MDMA (0.1-20 mg/kg, i.p.) on startle/PPI in both mice and rats.

Mice and rats were tested for acoustic startle reactivity in startle chambers (Ugo Basile apparatus, Milan, Italy) consisting of a sound-attenuated, lighted and ventilated enclosure holding a transparent non-restrictive Perspex ${ }^{\circledR}$ cage $(84 \times 39 \times 44 \mathrm{~mm}$ for mice and a modified version, $200 \times 90$ $\times 80 \mathrm{~mm}$, for rats). A loudspeaker mounted laterally by the holder produced all acoustic stimuli. Peak and amplitudes of the startle response were detected by a loadcell. At the onset of the startling stimulus, 300-ms readings were recorded and the wave amplitude evoked by the animal movement startle response was measured.

Acoustic startle test sessions consisted of startle trials (pulse-alone) and prepulse trials (prepulse + pulse). The pulse-alone trial consisted of a 40-ms 120-dB pulse. The prepulse + pulse trials sequence consisted of a $20-\mathrm{ms}$ acoustic prepulse, 80 -ms delay, and then a $40-\mathrm{ms} 120-\mathrm{dB}$ startle pulse (100-ms onset-onset). There was an average of $15 \mathrm{~s}$ (range $=$ from 9 to $21 \mathrm{~s}$ ) between the trials. Each startle session began with a 10-min acclimation period with a $65-\mathrm{dB}$ broadband white noise that was present continuously throughout the session. The test session contained 40 trials composed of pulse-alone and prepulse + pulse trials (with three different prepulses of $68-\mathrm{dB}, 75-\mathrm{dB}$ and $85-\mathrm{dB}$ ) presented in a pseudorandomized order. Animals were placed in the startle chambers 5 min after treatment with MDMA. The entire startle/PPI test lasted $20 \mathrm{~min}$. The amount of prepulse inhibition (PPI) was expressed as the percentage decrease in the amplitude of the startle reactivity caused by the presentation of the prepulse (\% PPI). MDMA $(0.1-20 \mathrm{mg} / \mathrm{kg})$ was administered intraperitoneally and startle/PPI responses were recorded 15 min (including the 10 min acclimation period) after drug injections.

\section{Data and statistical analysis}

In sensorimotor response experiments, data were expressed in arbitrary units (visual objects response, acoustic response, vibrissae, corneal and pinna reflex) and percentage of baseline (visual placing response). Spontaneous locomotion was expressed as a percentage of baseline and turning behaviour as number of rotations. The amount of PPI was calculated as a percentage score for each prepulse + pulse trial type: $\% \mathrm{PPI}=100-\{[$ (startle response for prepulse + pulse trial)/(startle response for pulse-alone trial) $] \times 100\}$. Startle magnitude was calculated as the average response to all pulse-alone trials. All the numerical data were given as mean \pm SEM (Standard Error of the Mean). In sensorimotor (Figs. 1,2) and locomotor activity (Fig. 3) experiments, the statistical analysis was performed by two-way ANOVA followed by Bonferroni's test for multiple comparisons. In startle/prepulse inhibition experiments (Fig. 4) the statistical analysis was performed by one-way ANOVA followed by Bonferroni's test for multiple comparisons. Statistical analysis was carried out using Prism software (GraphPad, San Diego, CA, USA).

\section{Results}

\section{Evaluation of the visual object response}

Visual object response did not change in saline-treated rats/ mice over the period of observation (Fig. 1a, b). Systemic administration of MDMA $(0.1-20 \mathrm{mg} / \mathrm{kg}$ i.p.) promptly reduced the visual object response in rats after $5 \mathrm{~min}$ and the effect persisted up to 60 min but disappeared at 6,16 and $24 \mathrm{~h}$ after injection [Fig. 1a; ANOVA detected a significant $(p<0.0001)$ effect of treatment $\left(F_{4,245}=23.75\right)$, 

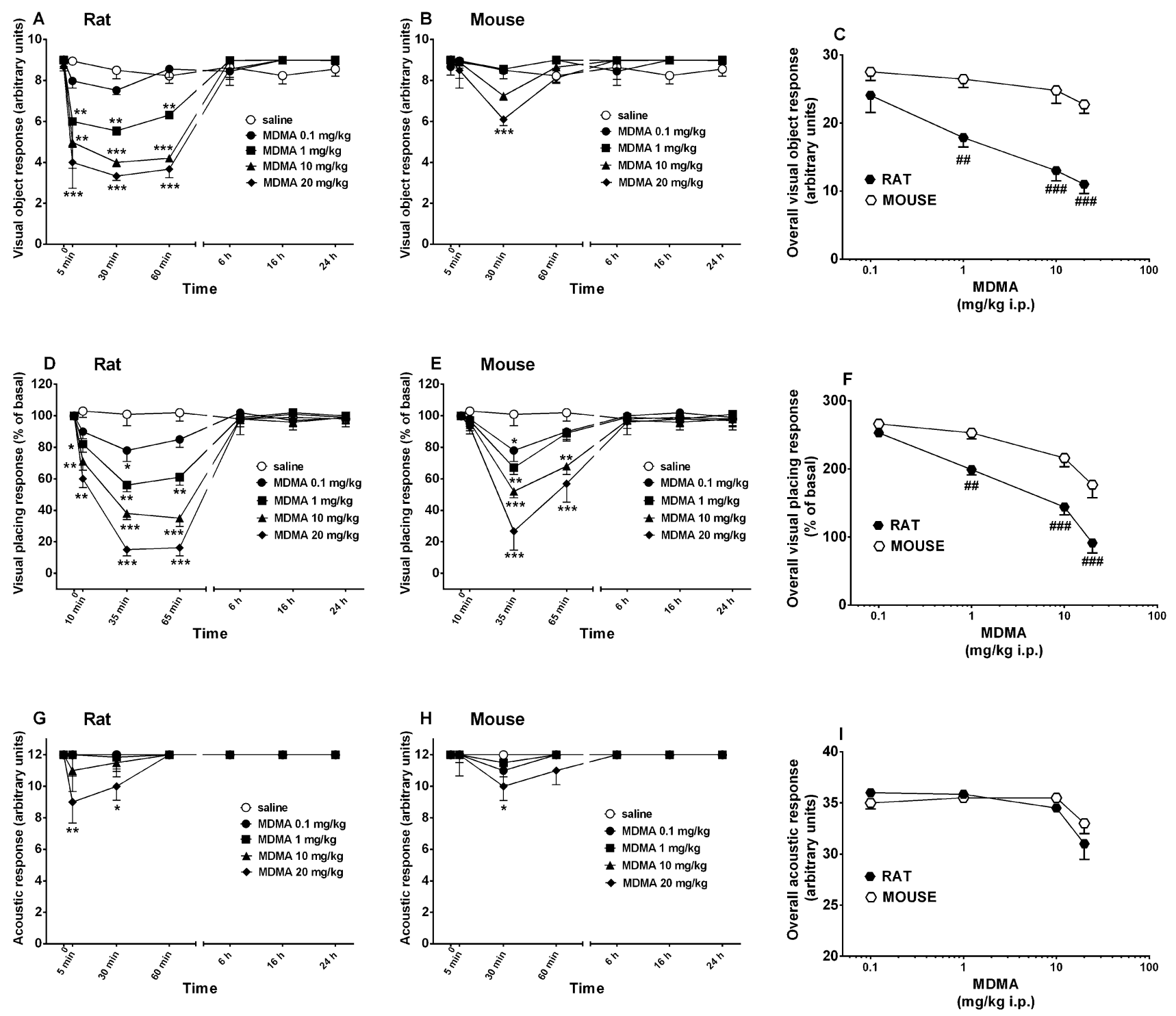

Fig. 1 Effect of the systemic administration of MDMA (0.1-20 mg/ $\mathrm{kg}$ i.p.) on the visual object test $(\mathbf{a}, \mathbf{b})$, the visual placing test (c, d) and the acoustic response test $(\mathbf{g}, \mathbf{h})$ in rats and mice. Comparison of the overall visual object (c), visual placing (f) and acoustic (i) responses in rats and mice. Overall responses were calculated in the time intervals between 5 and $60 \mathrm{~min}$ for the visual object (c) and acoustic (i) tests and in the time intervals between 10 and 65 min for

time $\left(F_{6,245}=47.64\right)$ and time $\times$ treatment interaction $\left.\left(F_{24,245}=6.576\right)\right]$, while MDMA reduced the visual object response in mice only at highest dose at $30 \mathrm{~min}$ after drug injection [Fig. 1b; ANOVA detected a significant effect of time $\left(F_{6,245}=4.448 ; p=0.003\right)$ but not treatment $\left(F_{4,245}=1.57 ; p=0.183\right)$ and time $\times$ treatment interaction $\left.\left(F_{24,245}=1.245 ; p=0.2044\right)\right]$. MDMA was more potent and effective in reducing the visual object response in rats than in mice [Fig. 1c; ANOVA detected a significant effect of treatment $\left(F_{3,56}=11.84 ; p<0.0001\right)$, species $\left(F_{1,56}=61.29\right.$; the visual placing test (f). Data are expressed (see "Materials and methods") as arbitrary units $(\mathbf{a}, \mathbf{b}, \mathbf{c}, \mathbf{g}, \mathbf{h}, \mathbf{i})$ or percentage of basal values $(\mathbf{d}-\mathbf{f})$ and represent the mean \pm SEM of eight animals for each treatment. Statistical analysis was performed by two-way ANOVA followed by Bonferroni's test for multiple comparisons. $* p<0.0125$, $* * p<0.0025$ and $* * * p<0.00025$ versus saline; ${ }^{\# \#} p<0.0025$ and

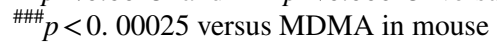

$p<0.0001)$ and species $\times$ treatment interaction $\left(F_{3,56}=2.97\right.$; $p=0.0395)]$.

\section{Evaluation of the visual placing response}

Visual placing response did not change in saline-treated rats/mice over the period of observation (Fig. 1d, e). Systemic administration of MDMA (0.1-20 mg/kg i.p.) reduced the visual placing response in rats at 10,35 and $65 \mathrm{~min}$, and the effect disappeared at 6, 16 and $24 \mathrm{~h}$ after injection [Fig. 1d; ANOVA detected a significant $(p<0.0001)$ 

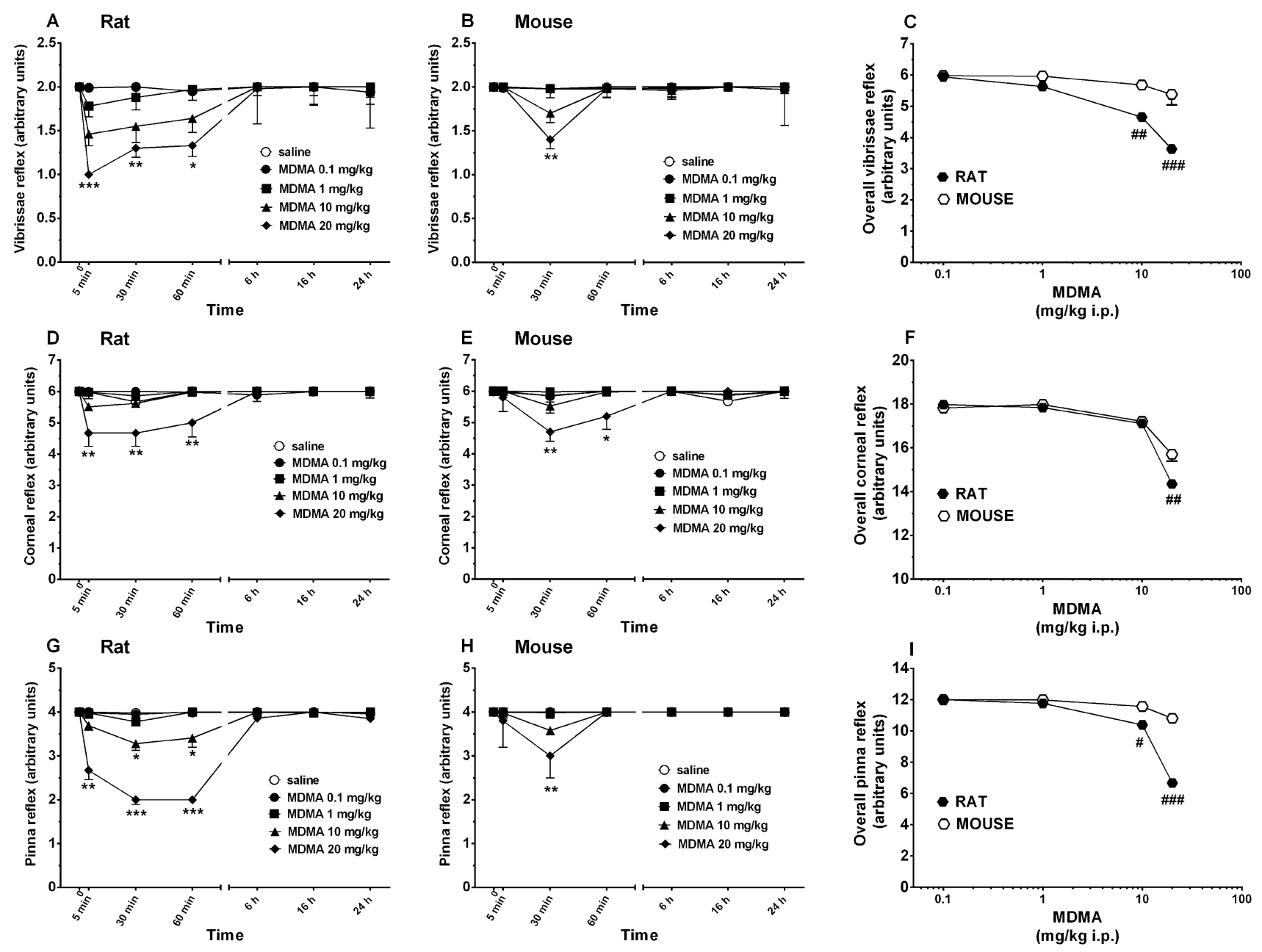

Fig. 2 Effect of the systemic administration of MDMA (0.1-20 mg/ $\mathrm{kg}$ i.p.) on the vibrissae $(\mathbf{a}, \mathbf{b})$, corneal $(\mathbf{c}, \mathbf{d})$ and pinnae $(\mathbf{g}, \mathbf{h})$ reflex in rat and mouse. Comparison of the overall vibrissae (c), visual (f) and acoustic (i) reflexes in rats and mice. Overall reflexes were calculated in the time intervals between 5 and $60 \mathrm{~min}$ for the vibrissae (c), corneal (f) and pinna tests. Data are expressed (see "Materials and methods") as arbitrary units (a-i) and represent the mean \pm SEM of eight animals for each treatment. Statistical analysis was performed by two-way ANOVA followed by Bonferroni's test for multiple comparisons. $* p<0.0125, * * p<0.0025$ and $* * * p<0.00025$ versus saline; ${ }^{\#} p<0.0125,{ }^{\# \#} p<0.0025$ and $^{\# \# \#} p<0.00025$ versus MDMA in mice

\section{Evaluation of the acoustic response}

and time $\times$ treatment interaction $\left.\left(F_{24,245}=11.28\right)\right]$. In mice, the impairment of visual placing response was delayed at 35 and 65 min after MDMA injection [Fig. 1e: ANOVA detected a significant $(p<0.0001)$ effect of treatment $\left(F_{4,245}=12.23\right)$, time $\left(F_{6,245}=27.82\right)$ and time $\times$ treatment interaction $\left.\left(F_{24,245}=3.899\right)\right]$. MDMA induced a more effective impairment of visual placing response in rats than in mice [Fig. 1f; ANOVA detected a significant effect of treatment $\left(F_{3,56}=44.61 ; p<0.0001\right)$, species $\left(F_{1,56}=46.88\right.$; $p<0.0001)$ and species $\times$ treatment interaction $\left(F_{3,56}=3.69\right.$; $p=0.0170)]$.
Acoustic response did not change in saline-treated rats/ mice over the period of observation (Fig. 1g, h). Administration of MDMA $(0.1-20 \mathrm{mg} / \mathrm{kg}$ i.p.) slightly reduced the acoustic response in rats at 5 and $30 \mathrm{~min}$ [Fig. 1g; ANOVA detected a significant effect of treatment $\left(F_{4,245}=4.448\right.$; $p=0.0403)$ but not time $\left(F_{6,245}=1.883 ; p=0.0843\right)$ and time $\times$ treatment interaction $\left.\left(F_{24,245}=0.9912 ; p=0.4784\right)\right]$ and mice at $30 \mathrm{~min}$ [Fig. 1h; ANOVA detected a significant effect of treatment $\left(F_{4,245}=3.748 ; p=0.047\right)$ but not time $\left(F_{6,245}=1.626 ; p=0.1404\right)$ and time $\times$ treatment interaction $\left.\left(F_{24,245}=0.3504 ; p=0.9983\right)\right]$ and the effect disappeared at 6,16 and $24 \mathrm{~h}$ after injection. The overall effects induced 

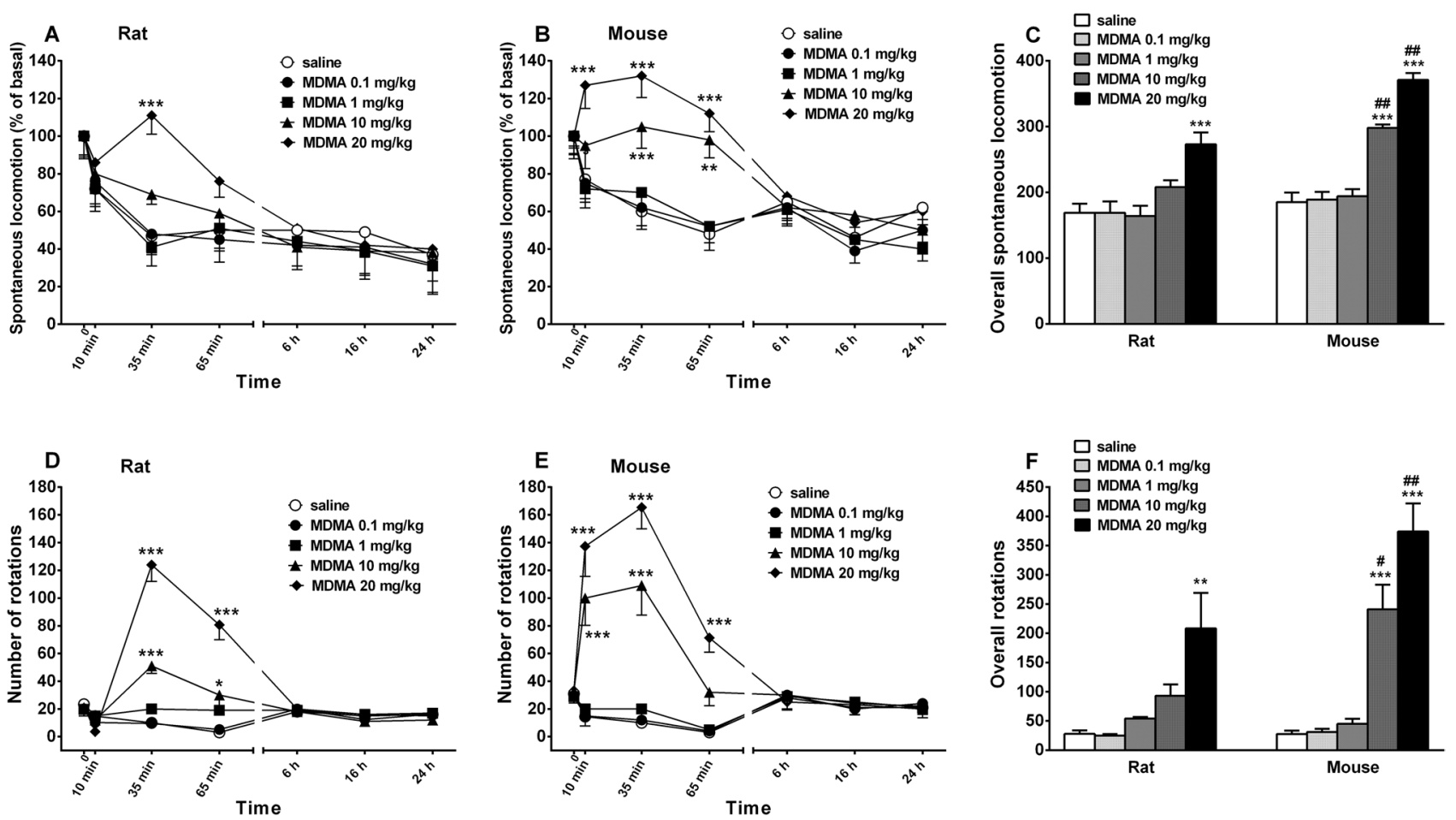

Fig. 3 Effect of the systemic administration of MDMA (0.1-20 mg/ $\mathrm{kg}$ i.p.) on spontaneous locomotion (a, b), and turning behaviour (d, e) in rats and mice. Comparison of overall spontaneous locomotion (c) and turning behaviour (f) in rats and mice. Overall motor activity was calculated in the time intervals between 10 and $65 \mathrm{~min}(\mathbf{c}, \mathbf{f})$. Data are expressed (see "Materials and methods") as a percentage of basal values $(\mathbf{a}-\mathbf{c})$ and number of rotations $(\mathbf{d}-\mathbf{f})$ and represent the mean \pm SEM of eight animals for each treatment. Statistical analysis was performed by two-way ANOVA followed by Bonferroni's test for multiple comparisons. $* p<0.0125, * * p<0.0025$ and $* * * p<0.00025$ versus saline; ${ }^{\#} p<0.0125$ and ${ }^{\# \#} p<0.0025$ versus MDMA in mice

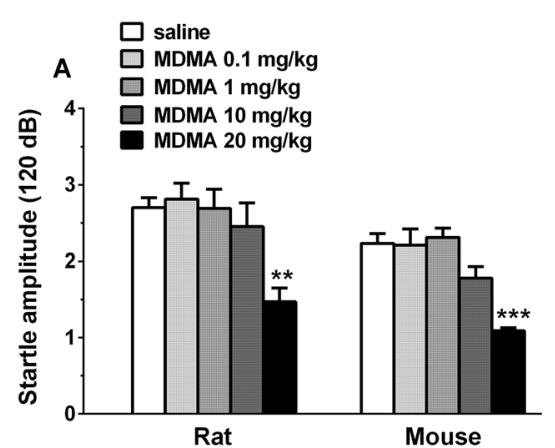

Rat

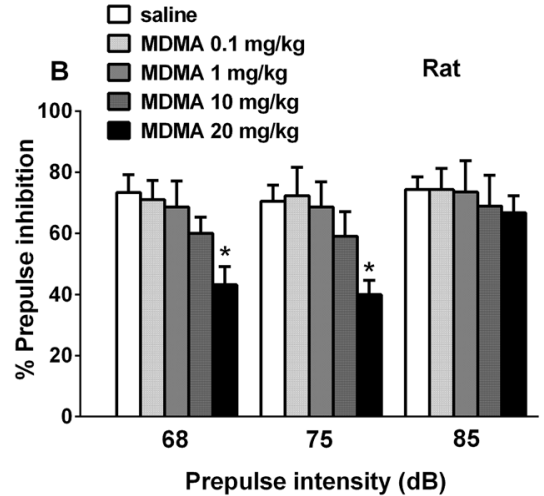

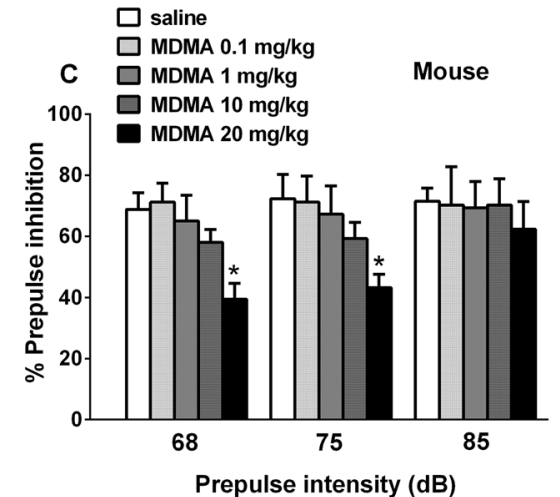

Fig. 4 Effect of the systemic administration of MDMA (0.1-20 mg/ $\mathrm{kg}$ i.p.) on startle amplitude (a) and pre-pulse inhibition (PPI) in the rats (b) and mice (c). Effects on PPI are shown for the three prepulse intensities $(68,75$ and $85 \mathrm{~dB}), 15$ min after treatment $(\mathbf{b}, \mathbf{c})$. Data are expressed (see "Materials and methods") as absolute values (dB; a) and percentage decrease in the amplitude of the startle reactiv-

by MDMA on acoustic response were not different in rats and mice (Fig. 1i). ity caused by presentation of the prepulse (\% PPI; b, c) and values represent mean \pm SEM of ten animals for each treatment. Statistical analysis was performed by one-way ANOVA followed by Bonferroni's test for multiple comparisons. ${ }^{*} p<0.0125$, $* * p<0.0025$ and $* * * p<0.000251$ versus saline

\section{Evaluation of the vibrissae reflex}

Vibrissae reflex did not change in saline-treated rats/ mice over the period of observation (Fig. 2a, b). Systemic 
administration of MDMA (0.1-20 mg/kg i.p.) promptly reduced the vibrissae reflex in rats at the highest dose after $5 \mathrm{~min}$, and the effect persisted for up to $60 \mathrm{~min}$ but disappeared at 6,16 and $24 \mathrm{~h}$ after injection [Fig. 1a; ANOVA detected a significant effect of treatment $\left(F_{4,245}=5.335\right.$; $p=0.0004)$, time $\left(F_{6,245}=4.372 ; p=0.0003\right)$ but not time $\times$ treatment interaction $\left(F_{24,245}=1.353 ; p=0.131\right)$ ], while MDMA reduced the visual object response in mice only at the highest dose at $30 \mathrm{~min}$ after drug injection [Fig. 1b; ANOVA detected a significant effect of time $\left(F_{6,245}=2.821\right.$; $p=0.0113)$ but not treatment $\left(F_{4,245}=1.178 ; p=0.3212\right)$ and time $\times$ treatment interaction $\left.\left(F_{24,245}=1.078 ; p=0.3699\right)\right]$. MDMA was more effective in reducing the vibrissae reflex in rats than in mice [Fig. 1c; ANOVA detected a significant $(p<0.0001)$ effect of treatment $\left(F_{3,56}=43.51\right)$, species $\left(F_{1,56}=61.41\right)$ and species $\times$ treatment interaction $\left.\left(F_{3,56}=14.47\right)\right]$.

\section{Evaluation of the corneal reflex}

Corneal reflex did not change in saline-treated rats/mice (Fig. 2d). Systemic administration of MDMA (0.1-20 mg/ $\mathrm{kg}$ i.p.) slightly reduced the corneal reflex in rats at 5,30 and $60 \mathrm{~min}$ (Fig. 2d; ANOVA detected a significant $(p<0.0001)$ effect of treatment $\left(F_{4,245}=14.64\right)$, time $\left(F_{6,245}=8.318\right)$ and time $\times$ treatment interaction $\left.\left(F_{24,245}=3.663\right)\right]$ and mice at 30 and $60 \mathrm{~min}$ [Fig. 2e; ANOVA detected a significant effect of treatment $\left(F_{4,245}=4.967 ; p=0.0007\right)$, time $\left(F_{6,245}=5.06\right.$ : $p<0.0001)$ and time $\times$ treatment interaction $\left(F_{24,245}=2.328\right.$; $p=0.0007)]$ and the effect disappeared at 6,16 and $24 \mathrm{~h}$ after injection. MDMA was more effective in reducing the corneal reflex in rats than in mice at $5 \mathrm{~min}$ after drug injection $(p<0.01)$. MDMA was more effective in reducing the corneal reflex in rats than in mice [Fig. 2d; ANOVA detected a significant effect of treatment $\left(F_{3,56}=107.5 ; p<0.0001\right)$, species $\left(F_{1,56}=7.482 ; p=0.0083\right)$ and species $\times$ treatment interaction $\left.\left(F_{3,56}=6.67 ; p=0.0006\right)\right]$.

\section{Evaluation of the pinnae reflex}

Pinnae reflex did not change in saline-treated rats/mice (Fig. 2g, h). Systemic administration of MDMA (0.1-20 mg/ $\mathrm{kg}$ i.p.) reduced the pinnae reflex in rats at 5,30 and $60 \mathrm{~min}$ [Fig. 2g; ANOVA detected a significant $(p<0.0001)$ effect of treatment $\left(F_{4,245}=164.5\right)$, time $\left(F_{6,245}=69.76\right)$ and time $\times$ treatment interaction $\left.\left(F_{24,245}=32.77\right)\right]$ and mice at $30 \mathrm{~min}$ [Fig. 2h; ANOVA detected a significant effect of time $\left(F_{6,245}=3.049 ; p=0.0068\right)$ but not treatment $\left(F_{4,245}=2.047\right.$; $p=0.0885)$ and time $\times$ treatment interaction $\left(F_{24,245}=1.407\right.$; $p=0.1034)$ ] and the effect disappeared at 6,16 and $24 \mathrm{~h}$ after injection. MDMA was more effective in reducing the pinnae reflex in rats than in mice [Fig. 2i; ANOVA detected a significant $(p<0.0001)$ effect of treatment $\left(F_{3,56}=201.0\right)$, species $\left(F_{1,56}=168.5\right)$ and species $\times$ treatment interaction $\left.\left(F_{3,56}=79.71\right)\right]$.

\section{Studies on spontaneous locomotor activity}

Horizontal spontaneous locomotor activity tended to decrease in saline-treated rats/mice $(\sim 60 \%$ reduction at 65 min; Fig. 3a, b). Systemic administration of MDMA $(0.1-20 \mathrm{mg} / \mathrm{kg}$ i.p.) increased the horizontal locomotor activity in rats [Fig. 3a; ANOVA detected a significant effect of treatment $\left(F_{4,245}=3.242 ; p=0.0129\right)$, time $\left(F_{6,245}=21.51 ; p<0.0001\right)$ but not time $\times$ treatment interaction $\left.\left(F_{24,245}=0.96 ; p=0.5202\right)\right]$ and mice [Fig. 3b; ANOVA detected a significant $(p<0.0001)$ effect of treatment $\left(F_{4,245}=16.73\right)$, time $\left(F_{6,245}=24.45\right)$ and time $\times$ treatment interaction $\left.\left(F_{24,245}=2.762\right)\right]$ and the effect disappeared at 6,16 and $24 \mathrm{~h}$ after injection. MDMA was more effective in facilitating locomotor activity in mice than in rats at 10 and $20 \mathrm{mg} / \mathrm{kg}$ [Fig. 3c; ANOVA detected a significant effect of treatment $\left(F_{4,70}=47.24 ; p<0.0001\right)$, species $\left(F_{1,70}=36.54 ; p<0.0001\right)$ and species $\times$ treatment interaction $\left.\left(F_{4,70}=4.5 ; p=0.0027\right)\right]$. MDMA also induced turning behaviour in rats at 35 and 65 min [Fig. 3d; ANOVA detected a significant $(p<0.0001)$ effect of treatment $\left(F_{4,245}=52.05\right)$, time $\left(F_{6,245}=36.22\right)$ and time $\times$ treatment interaction $\left.\left(F_{24,245}=26.08\right)\right]$ and mice at 10,35 and $65 \mathrm{~min}$ [Fig. 3e; ANOVA detected a significant $(p<0.0001)$ effect of treatment $\left(F_{4,245}=48.51\right)$, time $\left(F_{6,245}=20.95\right)$ and time $\times$ treatment interaction $\left.\left(F_{24,245}=12.86\right)\right]$ and the effect disappeared at 6,16 and $24 \mathrm{~h}$ after injection. MDMA was more effective in facilitating turning behaviour in mice than in rats at 10 and $20 \mathrm{mg} / \mathrm{kg}$ [Fig. 3f; ANOVA detected a significant effect of treatment $\left(F_{4,70}=31.67 ; p<0.0001\right)$, species $\left(F_{1,70}=11.49 ; p=0.0012\right)$ and species $\times$ treatment interaction $\left.\left(F_{4,70}=4.499 ; p=0.0027\right)\right]$.

\section{Startle/Prepulse inhibition studies}

Saline injection did not change startle/PPI response in rats and mice, and the effect was similar in naïve untreated animals (data not shown). Administration of MDMA $(0.1-20 \mathrm{mg} / \mathrm{kg}$, i.p.) impaired the startle amplitude both in rats and in mice [about $51 \%$ inhibition Fig. 4a; ANOVA detected a significant effect of treatment $\left(F_{4,70}=15.74\right.$; $p<0.0001)$, species $\left(F_{1,70}=17.78 ; p<0.0001\right)$ but not species $\times$ treatment interaction $\left(F_{4,70}=0.2440 ; p=0.9126\right)$ ] from $15 \mathrm{~min}$ to $35 \mathrm{~min}$ after MDMA administration. Moreover, MDMA inhibited the PPI in rats at 68 and $75 \mathrm{~dB}$ of prepulse intensity [Fig. 4b: ANOVA detected a significant effect of treatment $\left(F_{4,135}=5.347 ; p=0.0005\right)$, prepulse intensity $\left(F_{2,135}=2.546 ; p=0.082\right)$ but not prepulse intensity $\times$ treatment interaction $\left(F_{8,135}=0.5904 ; p=0.7845\right)$ ]. Similarly, MDMA inhibited the PPI in mice at 68 and $75 \mathrm{~dB}$ 
of prepulse intensity [Fig. 4c: ANOVA detected a significant effect of treatment $\left(F_{4,135}=4.532 ; p=0.0017\right)$, prepulse intensity $\left(F_{2,135}=1.575 ; p=0.2108\right)$ but not prepulse intensity $\times$ treatment interaction $\left(F_{8,135}=0.4874 ; p=0.8635\right)$ ]. The inhibitory effect of MDMA on startle/PPI in both rats and mice disappeared at $6 \mathrm{~h}$ after administration of the compound (data not shown).

\section{Discussion}

In this study we investigated the effects of pure MDMA compound $(0.1-20 \mathrm{mg} / \mathrm{kg}$ ) administration on sensorimotor response and on startle/prepulse inhibition paradigm in a controlled setting of animal (rodents) experiment. Our major findings were that all the MDMA-treated animals had impaired sensorimotor and prepulse inhibition responses compared to the control subjects at the early $(5,30$ and $60 \mathrm{~min}$ ) testing time point while all the observed effects disappeared, respectively, 6,16 and $24 \mathrm{~h}$ post MDMA treatment. The serotonin releasing agent also stimulates hyperlocomotion in both rats and mice.

Systemic high doses of MDMA administration promptly affected motor and sensorimotor responses in both rats and mice. In particular, sensorimotor responses were reduced as early as $\mathbf{5}$ min after drug administration. All observed effects reached a maximum in the time window ranging from $10 \mathrm{~min}$ to $70 \mathrm{~min}$ (depending on the behavioural test), and then they started to decrease. The rapid changes observed in sensorimotor functions reflected in vivo pharmacokinetic studies in rats showing that intraperitoneal administration of $10 \mathrm{mg} / \mathrm{kg}$ MDMA produced a rapid increase in circulating levels of MDMA over time-significantly higher compared with those for the subcutaneous and oral route. In particular, intraperitoneal injection of MDMA increased plasma levels of MDMA with maximum peak concentrations achieved by about 8 min after drug injection [32], while oral administration with MDMA increased plasma levels of MDMA with maximum peak concentrations achieved by about 30-60 min after MDMA injection [32]. Moreover, in a murine study, a high concentration of fluorine-18 and carbon11 labelled MDMA was detected in the brain of mice after 5 min from radiotracers intravenous injection [33]. The duration of the observed effects (i.e., 10-70 $\mathrm{min}$ ) is in line with previous in vivo microdialysis studies showing that systemic intraperitoneal MDMA administration promotes MDMA increase in the rodent brain. Systemic injection of $15 \mathrm{mg} /$ kg MDMA rapidly increased MDMA concentration in hippocampal dialysate of rats. The MDMA concentration was maximal between 30 and 60 min and then declined progressively [34]. This time-course of rise in MDMA concentrations in brain areas may account for the duration of in vivo 5-HT and DA (dopamine) release (i.e., ranging from 60 to
$120 \mathrm{~min}$ ) in brain areas of rodents $[35,36]$ and also for the observed behavioural effects. Immunohistochemical investigation revealed the encephalic distribution of the substance. De Letter et al. [37], in MDMA-related fatal cases, demonstrated a marked immunoreactivity (anti-MDMA) corresponding to neurons in all cortical regions, basal ganglia, hypothalamus, hippocampus, cerebellar vermis, and white matter. Our previous experimental study confirmed the topographic distribution of MDMA, showing a different distribution of MDMA over time, with a markedly positive reaction in the basal ganglia and thalamus in rats sacrificed at $6 \mathrm{~h}$ after treatment, and a subsequent weaker uniform positivity in the frontal cortex, striatum, hippocampus, and thalamus (16-24 h) [6].

MDMA-induced sensorimotor alterations, especially visual ones, might be due to the activation of selective serotonin receptor in cortical brain areas as typically reported for $5 \mathrm{HT}_{2 \mathrm{~A}}$ agonists [38]. Such hallucinogenic compounds exhibit high affinity for 5- $\mathrm{HT}_{2 \mathrm{~A}}$ receptors [39]. Genetic or pharmacological inactivation of $5 \mathrm{HT}_{2 \mathrm{~A}}$ receptor signalling blocks the behavioural effects of hallucinogenic compounds in a variety of species, including mice, rats, and humans [40]. Taken together, these findings indicate that 5-HT released by MDMA, through activating $5 \mathrm{HT}_{2 \mathrm{~A}}$ receptor in cortico-visual circuits, could impair sensorimotor responses, probably by promoting a 'disperceptive state'. In fact, MDMA reduces light startle and light prepulse inhibition in male albino Wistar rats [41]. The decrease in the acoustic response is consistent with the inhibition of startle reflex observed in the present study and with previous studies demonstrating that MDMA disrupts acoustic startle in both rats [30] and mice [31]. The impairment of acoustic responses could be related to the stimulation of specific serotonin receptor subtypes, since the administration of DOI (2,5-dimethoxy-4-iodoamphetamine), a $5 \mathrm{HT}_{2 \mathrm{~A}}$ receptor agonist, disrupted the acoustic startle response in Sprague-Dawley rats [42]. Recently, the role of serotonin has been demonstrated in modulating auditory brainstem responses in mice, starting from the cochlear nucleus [43]. Indeed, in the dorsal region of this nucleus, the activation of $5 \mathrm{HT}_{2}$ receptors increases the electrical activity of neurons, leading to the final suppression of the auditory process [44]. Besides the reduction of sensory responses to visual and acoustic stimuli, MDMA also reduces sensorimotor responses to tactile stimulation of the vibrissae, pinna and corneas. This effect is in accordance with previous studies that prove that the serotonin reuptake inhibitor fluoxetine decreases tactile startle in rats, via actions at 5- $\mathrm{HT}_{2}$ receptors [45]. Differently, Kehne and collaborators (1992) have shown that MDMA facilitates tactile startle reflex in rats by modulating ascending (dorsal raphe) and descending (spinal) serotonergic pathways [41]. Overall, these findings support the hypothesis that MDMA, enhancing the release 
of 5-HT, is directly involved in the modulation of the tactile sensorimotor response in animals.

Besides demonstrating the reduction of sensorimotor responses, our study shows that MDMA at $20 \mathrm{mg} / \mathrm{kg}$ also impairs acoustic sensorimotor gating in the startle/PPI paradigm in both rats and mice. Our results are in line with previous studies highlighting that MDMA disrupts startle and inhibits prepulse inhibition in rats [30] and some strains of mice [31]. PPI deficits in rodents could be related to an increase in 5-HT and DA induced by MDMA [46]. Our study confirms that the effect of MDMA on the outbred ICR mouse strain [47] more closely resembles the effects of MDMA in outbred rats, which is to reduce sensorimotor gating at multiple prepulse intensities [30]. Sensorimotor gating is a neural mechanism that inhibits extraneous sensory, cognitive, and motor information to permit mental integration and adaptive behaviour. Prepulse inhibition, an operational measure of sensorimotor gating, is a neurological phenomenon in which a weaker prestimulus (prepulse) inhibits the reaction of an organism to a subsequent strong startling stimulus [48]. PPI levels indicate the current integrity of sensorimotor gating mechanisms by measuring the extent to which current information processing routines elicited by the prepulse are interrupted by the subsequent startling stimulus, and PPI is considered a useful biomarker in elucidating neurobiological substrates underlying several neuropsychiatric disorders [49].

Overall, these data clearly demonstrate that a dose of $20 \mathrm{mg} / \mathrm{kg}$ MDMA not only disrupts the ability of animals to receive external information (visual, acoustic and tactile) but also impairs sensorimotor integration. In our study we used a dose of MDMA (20 mg/kg) which stimulated locomotion and induced motor stereotypies (i.e., body rotations) both in mice and rats [29]. MDMA-induced motor activation in rodents was related to the increased release of 5-HT and DA in the basal ganglia and specifically in striatal nuclei $[35,36$, 50]. According to the hypothesis of Sprague et al. (1998), acute doses of MDMA initially released 5-HT. Serotonin released by MDMA decreases inhibitory GABAergic transmission via $5-\mathrm{HT}_{2 \mathrm{~A} / \mathrm{C}}$ receptors situated on GABA interneurons, and this increases DA release [51]. The fact that both serotoninergic and dopaminergic transmission are directly involved in the MDMA-induced motor effect is confirmed by genetic and pharmacological in vivo studies. In knockout mice lacking 5- $\mathrm{HT}_{1 \mathrm{~B}}$ receptor, locomotor response was abolished after MDMA administration [52], while hyperactivity induced by a high dose $(20 \mathrm{mg} / \mathrm{kg})$ of $( \pm)$-MDMA was attenuated by antagonists with affinity for $5-\mathrm{HT}_{1 \mathrm{~B} / 1 \mathrm{D}}$ and 5- $\mathrm{HT}_{2 \mathrm{~A} / 2 \mathrm{C}}$ receptors, and even DA receptors [53]. Similarly, McCreary and colleagues show that (+)-MDMA-induced hyperactivity is prevented by blocking the $5-\mathrm{HT}_{1 \mathrm{~B} / 1 \mathrm{D}}$ receptors and to a lesser extent the 5- $\mathrm{HT}_{1 \mathrm{~A}}$ receptors [54]. Moreover, some studies indicate that ( \pm )-MDMA, S(+)-MDMA, and $\mathrm{R}(-)$-MDMA induced ipsilateral rotation in unilateral 6-hydroxydopamine lesioned rats, which suggests a prominent role for the release of dopamine at the doses employed $[55,56]$. In our study the evidence that MDMA increases motor activity in the mouse more than in the rat is in accordance with recent microdialysis studies in mice that have shown that the effect of MDMA on 5-HT release was less potent than that on DA release. This does not correspond to the rank order of potency for MDMA inhibition of the DA and 5-HT uptake in vitro, where MDMA exhibits a higher potency at serotonin transporter (SERT) than at dopamine transporter (DAT) [57]. However, it has to be noted that MDMA has the ability to directly bind to a number of classical neurotransmitter receptors that may contribute to a stronger MDMA effect on DA release. For instance, MDMA, by acting directly on brain nicotinic acetylcholine receptors, may increase striatal DA release [58]. These pharmacodynamic factors, associated with the different metabolism of MDMA, may underlie the different efficacy and potency of MDMA in modulating locomotor activity and sensorimotor responses in rats and mice.

The effects of MDMA on basic cognitive skills in humans are still debated. Authors report that simple reaction time, visual attention, vigilance and other basic cognitive skills generally remain unaltered in abstinent Ecstasy/MDMA users [59]. On the other hand, some basic skills may be affected in the case of high information processing loads, or dual-task processing [8]. Tasks requiring the recall of spatial stimulus elements, figural recognition, and production/ reproduction of figures are reported to be mainly affected in Ecstasy/MDMA [60]. Conclusively, while many simple cognitive skills seem to be unaffected, there is extensive evidence of deficits in memory and higher information processing [8].

Furthermore, several studies suggest that MDMA has task specific effects on driving. According to recently published data, MDMA accounts for a remarkable number of fatalities, and it is detectable at a significant rate for traffic accidents [61]. However, as for many other drugs of abuse [16], a complex link between MDMA and driving is reported in the literature [62], suggesting that while MDMA could improve performance in some driving domains, other similarly relevant driving items could be negatively affected by MDMA [62].

In a recent systemic review of observational studies, Hayley et al. [63] showed, as best literature evidence, a conflicting level of evidence for associations between the use of amphetamine-type substances and the risk of traffic accidents. On the one hand, these authors report that limited and not univocal experimental data exist, showing that amphetamine-type substances can reduce certain behavioural and cognitive domains which are significant for driving ability, thus potentially leading to an increased risk 
of traffic accidents and fatalities. On the other hand, other authors do not report such an association [64, 65]. Finally, it has to be kept in mind that MDMA is often consumed in typical environmental conditions (dance clubs, rave parties, sleep deprivation) [5] that may interfere with MDMA effects [7]. Consequently, it is still debatable as to what extent the effects reported by MDMA abusers are specifically attributable to their MDMA consumption rather that to other concomitant, circumstantial situations and/or to the lack of distinction between illicit substances.

Conclusively, the effects of MDMA on driving and other human activity requiring skill and attention are not definitively and univocally ascertained; however, despite the existing clear dissociation of effects on different aspects of human performance, MDMA is an issue of some significance to public health and safety [66].

The present experimental study strongly supports the existing concerns regarding the recreational abuse of MDMA, from a particular methodological angle. The main characteristic of our investigation is that drug dosing and time of the response are controlled exactly and thus the actual effects of MDMA on some peculiar attentional skills are reported. Furthermore, high-dose effects of stimulants on driving performance cannot be readily assessed in experimental, placebo-controlled studies due to obvious medical and ethical constraints [62], while our animal model offers a look at the effects of high doses of MDMA alone with a closely monitored response correlation over time that may provide interesting information on the safety of MDMA in certain human activities. On the other hand, there is a limitation in that MDMA use is not observed in a natural environmental state such as in society [66].

\section{Conclusions}

In our study the use of a controlled animal (rodents) model in a neutral setting reveals acute prominent changes in sensorimotor and attentional performance, sensor response to external stimuli, and locomotor activity due to a single administration of a dose of MDMA (corresponding to a dose producing in humans both 'desirable, positive' entactogen effects and adverse physiological effects, such as tachycardia, trismus and bruxism).

Within the still ongoing debate on the safety of recreational abuse of MDMA [61-66] our results, obtained using high doses of MDMA alone in a controlled experimental environment without concurrent different psychoactive substances, could help to provide evidence as to whether the use of amphetamine-like substances such as MDMA could acutely impair some functions (visual, acoustic, tactile responses, sensorimotor integration) that are fundamental in many facets of life (driving and workplace performance).
Acknowledgements This research has been funded by the Drug Policies Department, Presidency of the Council of Ministers, Italy (project NS-Drugs to M. Marti) and by local funds from the University of Ferrara (FAR 2016 and FAR 2017 to M. Marti).

\section{Compliance with ethical standards}

Conflict of interest All the authors declare no competing interest.

Ethical approval The study on animals is compliance with ethical standards.

\section{References}

1. Johnston L, O’Malley P, Bachman J, Schulenberg JE (2012) Monitoring the future: national results on adolescent drug use: overview of key findings, 2011. Institute for Social Research, The University of Michigan, Ann Arbor. http://www.monitoringthefu ture.org/pubs/monographs/mtf-overview2015.pdf. Accessed on 10 Aug 2018

2. Dumont GJ, Verkes RJ (2006) A review of acute effects of 3,4-methylenedioxymethamphetamine in healthy volunteers. J Psychopharmacol 20:176-187

3. Sumnall HR, Cole JC, Jerome L (2006) The varieties of ecstatic experience: an exploration of the subjective experiences of ecstasy. J Psychopharmacol 20:670-682

4. Carvalho M, Carmo H, Costa VM, Capela JP, Pontes H, Remiao F, Carvalho F, Bastos Mde L (2012) Toxicity of amphetamines: an update. Archives Toxicol 86:1167-1231

5. Moratalla R, Khairnar A, Simola N, Granado N, Garcia-Montes JR, Porceddu PF, Tizabi Y, Costa G, Morelli M (2017) Amphetamine-related drugs neurotoxicity in humans and in experimental animals: main mechanisms. Prog Neurobiol 155:149-170

6. Riezzo I, Cerretani D, Fiore C, Bello S, Centini F, D’Errico S, Fiaschi AI, Giorgi G, Neri M, Pomara C, Turillazzi E, Fineschi V (2010) Enzymatic-nonenzymatic cellular antioxidant defense systems response and immunohistochemical detection of MDMA, VMAT2, HSP70, and apoptosis as biomarkers for MDMA (Ecstasy) neurotoxicity. J Neurosci Res 88:905-916

7. Meyer JS (2013) 3,4-methylenedioxymethamphetamine (MDMA): current perspectives. Subst Abuse Rehabil 4:83-99

8. Parrott AC (2013) Human psychobiology of MDMA or 'Ecstasy': an overview of 25 years of empirical research. H Psychopharmacol 28:289-307

9. Lamers CT, Ramaekers JG, Muntjewerff ND, Sikkema KL, Samyn N, Read NL, Brookhuis KA, Riedel WJ (2003) Dissociable effects of a single dose of ecstasy (MDMA) on psychomotor skills and attentional performance. J Psychopharmacol 17:379-387

10. Dumont GJ, Wezenberg E, Valkenberg MM, de Jong CA, Buitelaar JK, van Gerven JM, Verkes RJ (2008) Acute neuropsychological effects of MDMA and ethanol (co-)administration in healthy volunteers. Psychopharmacology 197:465-474

11. Ramaekers JG, Kuypers KP (2006) Acute effects of 3,4-methylenedioxymethamphetamine (MDMA) on behavioral measures of impulsivity: alone and in combination with alcohol. Neuropsychopharmacology 31:1048-1055

12. Kuypers KP, Ramaekers JG (2005) Transient memory impairment after acute dose of $75 \mathrm{mg}$ 3.4-methylene-dioxymethamphetamine. J Psychopharmacol 19:633-639

13. Bosker WM, Kuypers KP, Conen S, Kauert GF, Toennes SW, Skopp G, Ramaekers JG (2012) MDMA (ecstasy) effects on actual driving performance before and after sleep deprivation, 
as function of dose and concentration in blood and oral fluid. Psychopharmacology 222:367-376

14. Martin JK, Kraft JM, Roman PM (1994) extent and impact of alcohol and drug use problems in the workplace. In: Macdonald $\mathrm{S}$, Roman P (eds) Drug testing in the workplace. Springer, Boston, pp 3-31

15. Kuypers KP, Wingen M, Samyn N, Limbert N, Ramaekers JG (2007) Acute effects of nocturnal doses of MDMA on measures of impulsivity and psychomotor performance throughout the night. Psychopharmacology 192:111-119

16. Bosanquet D, Macdougall HG, Rogers SJ, Starmer GA, McKetin R, Blaszczynski A, McGregor IS (2013) Driving on ice: impaired driving skills in current methamphetamine users. Psychopharmacology 225:161-172

17. Matthews AJ, Bruno R, Dietze P, Butler K, Burns L (2014) Driving under the influence among frequent ecstasy consumers in Australia: trends over time and the role of risk perceptions. Drug Alcohol Depend 144:218-224

18. Edvardsen HM, Moan IS, Christophersen AS, Gjerde H (2015) Use of alcohol and drugs by employees in selected business areas in Norway: a study using oral fluid testing and questionnaires. J Occup Med Toxicol 10:46

19. Mohamed WM, Ben Hamida S, Cassel JC, de Vasconcelos AP, Jones BC (2011) MDMA: interactions with other psychoactive drugs. Pharmacol Biochem Behav 99:759-774

20. Morefield KM, Keane M, Felgate P, White JM, Irvine RJ (2011) Pill content, dose and resulting plasma concentrations of 3,4-methylendioxymethamphetamine (MDMA) in recreational 'ecstasy' users. Addiction 106:1293-1300

21. Cerretani D, Bello S, Cantatore S, Fiaschi AI, Montefrancesco G, Neri M, Pomara C, Riezzo I, Fiore C, Bonsignore A, Turillazzi E, Fineschi V (2011) Acute administration of 3,4-methylenedioxymethamphetamine (MDMA) induces oxidative stress, lipoperoxidation and TNFalpha-mediated apoptosis in rat liver. Pharmacol Res 64:517-527

22. Neri M, Bello S, Bonsignore A, Centini F, Fiore C, Foldes-Papp Z, Turillazzi E, Fineschi V (2010) Myocardial expression of TNF-alpha, IL-1beta, IL-6, IL-8, IL-10 and MCP-1 after a single MDMA dose administered in a rat model. Curr Pharmaceut Biotechnol 11:413-420

23. Cami G, Server-Carrio J, Fustero S, Pedregosa J (2000) A novel heterocyclic sulfonamide: N-benzyl-5-[N-benzyl-N-(tert-butyloxycarbonyl)amino]-N-(tert-butyloxycarbonyl)-1, 3,4-thiadiazole2-sulfonamide. Acta Crystallographica. Section C, Crystal Struct Commun 56:E209-E210

24. Hamdam J, Sethu S, Smith T, Alfirevic A, Alhaidari M, Atkinson J, Ayala M, Box H, Cross M, Delaunois A, Dermody A, Govindappa K, Guillon J-M, Jenkins R, Kenna G, Lemmer B, Meecham K, Olayanju A, Pestel S, Rothfuss A, Sidaway J, SisonYoung R, Smith E, Stebbings R, Tingle Y, Valentin J-P, Williams A, Williams D, Park K, Goldring C (2013) Safety pharmacology-current and emerging concepts. Toxicol Appl Pharmacol 273:229-241

25. Canazza I, Ossato A, Trapella C, Fantinati A, De Luca MA, Margiani G, Vincenzi F, Rimondo C, Di Rosa F, Gregori A, Varani K, Borea PA, Serpelloni G, Marti M (2016) Effect of the novel synthetic cannabinoids AKB48 and 5F-AKB48 on "tetrad", sensorimotor, neurological and neurochemical responses in mice. In vitro and in vivo pharmacological studies. Psychopharmacology 233:3685-3709

26. Ossato A, Canazza I, Trapella C, Vincenzi F, De Luca MA, Rimondo C, Varani K, Borea PA, Serpelloni G, Marti M (2016) Effect of JWH-250, JWH-073 and their interaction on "tetrad", sensorimotor, neurological and neurochemical responses in mice. Prog Neuro-Psychopharmacol Biol Psychiat 67:31-50
27. Ossato A, Vigolo A, Trapella C, Seri C, Rimondo C, Serpelloni G, Marti M (2015) JWH-018 impairs sensorimotor functions in mice. Neuroscience 300:174-188

28. Koch S, Galloway MP (1997) MDMA induced dopamine release in vivo: role of endogenous serotonin. J Neural Transm 104:135-146

29. Fantegrossi WE, Godlewski T, Karabenick RL, Stephens JM, Ullrich T, Rice KC, Woods JH (2003) Pharmacological characterization of the effects of 3,4-methylenedioxymethamphetamine ("ecstasy") and its enantiomers on lethality, core temperature, and locomotor activity in singly housed and crowded mice. Psychopharmacology 166:202-211

30. Mansbach RS, Braff DL, Geyer MA (1989) Prepulse inhibition of the acoustic startle response is disrupted by N-ethyl-3,4-methylenedioxyamphetamine (MDEA) in the rat. Eur J Pharmacol 167:49-55

31. van den Buuse M, Becker T, Kwek P, Martin S, Ruimschotel E, Risbrough V (2011) Disruption of prepulse inhibition by 3,4-methylenedioxymethamphetamine (MDMA): comparison between male and female wild-type and 5-HT(1A) receptor knockout mice. Int J Neuropsychopharmacol 14:856-861

32. Baumann MH, Zolkowska D, Kim I, Scheidweiler KB, Rothman RB, Huestis MA (2009) Effects of dose and route of administration on pharmacokinetics of (+ or -)-3,4-methylenedioxymethamphetamine in the rat. Drug Metab Dispos 37:2163-2170

33. Shiue CY, Shiue GG, Rysavy JA, Pleus RC, Huang H, Bai LQ, Cornish KG, Sunderland JJ, Frick MP (1993) Fluorine-18 and carbon-11 labeled amphetamine analogs-synthesis, distribution, binding characteristics in mice and rats and a PET study in monkey. Nucl Med Biol 20:973-981

34. Esteban B, O'Shea E, Camarero J, Sanchez V, Green AR, Colado MI (2001) 3,4-Methylenedioxymethamphetamine induces monoamine release, but not toxicity, when administered centrally at a concentration occurring following a peripherally injected neurotoxic dose. Psychopharmacology 154:251-260

35. Gorska AM, Golembiowska K (2015) The role of adenosine A1 and $\mathrm{A} 2 \mathrm{~A}$ receptors in the caffeine effect on MDMA-induced DA and 5-HT release in the mouse striatum. Neurotox Res 27:229-245

36. Yamamoto BK, Nash JF, Gudelsky GA (1995) Modulation of methylenedioxymethamphetamine-induced striatal dopamine release by the interaction between serotonin and gamma-aminobutyric acid in the substantia nigra. J Pharmacol Exp Ther 273:1063-1070

37. De Letter EA, Espeel MF, Craeymeersch ME, Lambert WE, Clauwaert KM, Dams R, Mortier KA, Piette MH (2003) Immunohistochemical demonstration of the amphetamine derivatives 3,4-methylenedioxymethamphetamine (MDMA) and 3,4-methylenedioxyamphetamine (MDA) in human post-mortem brain tissues and the pituitary gland. Int J Legal Med 117:2-9

38. Canal CE, Morgan D (2012) Head-twitch response in rodents induced by the hallucinogen 2,5-dimethoxy-4-iodoamphetamine: a comprehensive history, a re-evaluation of mechanisms, and its utility as a model. Drug Test Anal 4:556-576

39. Gonzalez-Maeso J, Sealfon SC (2009) Agonist-trafficking and hallucinogens. Curr Med Chem 16:1017-1027

40. Gonzalez-Maeso J, Weisstaub NV, Zhou M, Chan P, Ivic L, Ang R, Lira A, Bradley-Moore M, Ge Y, Zhou Q, Sealfon SC, Gingrich JA (2007) Hallucinogens recruit specific cortical 5-HT(2A) receptor-mediated signaling pathways to affect behavior. Neuron 53:439-452

41. Kehne JH, McCloskey TC, Taylor VL, Black CK, Fadayel GM, Schmidt CJ (1992) Effects of the serotonin releasers 3,4-methylenedioxymethamphetamine (MDMA), 4-chloroamphetamine (PCA) and fenfluramine on acoustic and tactile startle reflexes in rats. $\mathrm{J}$ Pharmacol Exp Ther 260:78-89 
42. Swerdlow NR, Geyer MA, Shoemaker JM, Light GA, Braff DL, Stevens KE, Sharp R, Breier M, Neary A, Auerbach PP (2006) Convergence and divergence in the neurochemical regulation of prepulse inhibition of startle and $\mathrm{N} 40$ suppression in rats. Neuropsychopharmacology 31:506-515

43. Papesh MA, Hurley LM (2016) Modulation of auditory brainstem responses by serotonin and specific serotonin receptors. Hearing Res 332:121-136

44. Felix RA 2nd, Elde CJ, Nevue AA, Portfors CV (2017) Serotonin modulates response properties of neurons in the dorsal cochlear nucleus of the mouse. Hearing Res 344:13-23

45. Geyer MA, Tapson GS (1988) Habituation of tactile startle is altered by drugs acting on serotonin-2 receptors. Neuropsychopharmacology 1:135-147

46. Geyer MA, Krebs-Thomson K, Braff DL, Swerdlow NR (2001) Pharmacological studies of prepulse inhibition models of sensorimotor gating deficits in schizophrenia: a decade in review. Psychopharmacology 156:117-154

47. Dulawa SC, Geyer MA (2000) Effects of strain and serotonergic agents on prepulse inhibition and habituation in mice. Neuropharmacology 39:2170-2179

48. Graham FK (1975) Presidential Address. 1974. The more or less startling effects of weak prestimulation. Psychophysiology $12: 238-248$

49. Siegel SJ, Talpos JC, Geyer MA (2013) Animal models and measures of perceptual processing in schizophrenia. Neurosci Biobehav Rev 37:2092-2098

50. White SR, Duffy P, Kalivas PW (1994) Methylenedioxymethamphetamine depresses glutamate-evoked neuronal firing and increases extracellular levels of dopamine and serotonin in the nucleus accumbens in vivo. Neuroscience 62:41-50

51. Sprague JE, Everman SL, Nichols DE (1998) An integrated hypothesis for the serotonergic axonal loss induced by 3,4-methylenedioxymethamphetamine. Neurotoxicology 19:427-441

52. Scearce-Levie K, Viswanathan SS, Hen R (1999) Locomotor response to MDMA is attenuated in knockout mice lacking the 5-HT1B receptor. Psychopharmacology 141:154-161

53. Kehne JH, Ketteler HJ, McCloskey TC, Sullivan CK, Dudley MW, Schmidt CJ (1996) Effects of the selective 5-HT2A receptor antagonist MDL 100,907 on MDMA-induced locomotor stimulation in rats. Neuropsychopharmacology 15:116-124

54. McCreary AC, Bankson MG, Cunningham KA (1999) Pharmacological studies of the acute and chronic effects of (+)-3, 4-methylenedioxymethamphetamine on locomotor activity: role of 5-hydroxytryptamine(1A) and 5-hydroxytryptamine(1B/1D) receptors. J Pharmacol Exp Ther 290:965-973

55. Lebsanft HB, Mayerhofer A, Kovar KA, Schmidt WJ (2003) Is the Ecstasy-induced ipsilateral rotation in 6-hydroxydopamine unilaterally lesioned rats dopamine independent? J Neural Transm 110:707-718

56. Lebsanft HB, Kohles T, Kovar KA, Schmidt WJ (2005) 3,4-Methylenedioxymethamphetamine counteracts akinesia enantioselectively in rat rotational behavior and catalepsy. Synapse $55: 148-155$

57. Han DD, Gu HH (2006) Comparison of the monoamine transporters from human and mouse in their sensitivities to psychostimulant drugs. BMC Pharmacol 6:6

58. Faure P, Tolu S, Valverde S, Naude J (2014) Role of nicotinic acetylcholine receptors in regulating dopamine neuron activity. Neuroscience 282:86-100

59. Back-Madruga C, Boone KB, Chang L, Grob CS, Lee A, Nations H, Poland RE (2003) Neuropsychological effects of 3,4-methylenedioxymethamphetamine (MDMA or ecstasy) in recreational users. Clin Neuropsychol 17:446-459

60. Murphy PN, Bruno R, Ryland I, Wareing M, Fisk JE, Montgomery C, Hilton J (2012) The effects of 'ecstasy' (MDMA) on visuospatial memory performance: findings from a systematic review with meta-analyses. Human Psychopharmacol 27:113-138

61. Santacroce R, Ruiz Bennasar C, Sancho Jaraiz JR, Fiori F, Sarchione F, Angelini F, Catalano G, Carenti ML, Corkery JM, Schifano F, Di Giannantonio M, Martinotti G (2017) A matter of life and death: substance-caused and substance-related fatalities in Ibiza in 2015. Human Psychopharmacol 32(3):e2592

62. Ramaekers JG, Kuypers KP, Bosker WM, Brookhuis KA, Veldstra JA, Simons R, Martens M, Hjälmdahl M, Forsman A, Knoche A (2012) Effects of stimulant drugs on actual and simulated driving: perspectives from four experimental studies conducted as part of the DRUID research consortium. Psychopharmacology 222:413-418

63. Brookhuis KA, de Waard D, Samyn N (2004) Effects of MDMA (ecstasy), and multiple drugs use on (simulated) driving performance and traffic safety. Psychopharmacology 173:440-445

64. Silber BY, Croft RJ, Downey LA, Papafotiou K, Camfield DA, Stough C (2012) The effect of d-methamphetamine on simulated driving performance. Human Psychopharmacol 27:139-144

65. Hayley AC, Downey LA, Shiferaw B, Stough C (2016) Amphetamine-type stimulant use and the risk of injury or death as a result of a road-traffic accident: a systematic review of observational studies. Europ Neuropsychopharmacol 26:901-922

66. Bosanquet D, Macdougall HG, Rogers SJ, Starmer GA, McKetin R, Blaszczynski A, McGregor IS (2013) Driving on ice: impaired driving skills in current methamphetamine users. Psychopharmacology 225:161-172 